\title{
PENDIDIKAN ISLAM PLURALIS DAN MULTIKULTURAL
}

\author{
Oleh: Muhammad Yahya*
}

\begin{abstract}
Pluralism denotes an acceptance of plurality in the community. Plurality in terms of diversity means that human from different background live together under no circumstances. There are different reasons why diversity occurs. It may because of the way of thinking and the attitude to an object which is due to different life styles. The plural and multicultural concept in Islamic Education is equivalent to the concept of 'silaturrahim', which means a mutual respect and love among the creatures regardless of ethnic and religious background. Islamic Education does not only concern the hereafter, but the worldly life as well through integrated education.
\end{abstract}

KEYWORDS: Pendidikan Islam, pluralis, multikultural

PENDIDIKAN dalam Islam tidak sesempit yang dipahami oleh segelintir orang, yakni adanya di antara mereka memahami pendidikan Islam hanya berkisar pada pendidikan rohaniah semata, tanpa menyentuh pendidikan yang sifatnya pengembangan ilmu pengetahuan dan teknologi. Demikian pula bahwa sangatlah tidak tepat anggapan yang mengatakan Islam itu sangat eksklusif dan tertutup, tidak siap menerima perbedaan dan keragaman. Oleh karena itu untuk menilai Islam, seseorang harus memahami Islam secara sempurna atau secara $k a f f a h .{ }^{1}$ Dari segi historis misalnya, Islam telah mempraktekkan hidup rukun dalam keragaman, Nabi saw. membangun Yatsrib yang kemudian menjadi pusat pemerintahan, yang ditandai dengan perubahan nama menjadi Madinah yang terdiri atas keragaman etnis dan latar belakang agama dan kepercayaan, Nabi menerapkan konsep Al-Qur'an tidak memaksakan umat non Islam untuk terjadinya konversi ke Islam. ${ }^{2}$ Dengan ikhlas umat Islam membangun kebersaamaan yang plural di Madinah, namun karena ulah kaum Yahudi dari Bani Nadhir, ${ }^{3}$ maka Nabi kemudian memerintahkan mengusir mereka dari Madinah. ${ }^{4}$

Maka sangatlah tidak tepat bagi yang sering membuat statement yang seakan konsep pendidikan Islam hanya berkisar pada pencapaian kehidup-

*Kandidat doktor dalam bidang Hadis pada Program Pascasarjana Universitas Islam Negeri Alauddin Makassar ini adalah dosen tetap Fakultas Tarbiyah dan Keguruan UIN Alauddin dan sedang menjabat Ketua Prodi Manajemen Pendidikan Islam. 
an rohani penganutnya dan tidak menyentuh kehidupan umat yang secara menyeluruh (universalisme). Bahkan kalangan muslim yang tidak mempelajari Islam secara detail dan universal (kaffah) dengan mudah menyerap konsep-konsep pendidikan yang datangnya dari luar Islam yang nota bene konsep itu terkadang bertolak belakang dengan ajaran pokok Islam, sebab selain bisa merusak sendi-sendi keIslaman, yang mencakup lemahnya nilai-nilai kejuangan, juga bisa merusak sendi yang sangat pundamental yaitu aqidah umat. Inilah juga yang menyebabkan sehingga konsep pluralis universal yang multikultural seakan barang yang istimewa yang ditawarkan kalangan umat tanpa melalui filter yang seksama. Ketika umat menganggap telah menemukan peradaban baru, yang datangnya dari nege-ri seberang seakan cepat ingin disergap, tanpa melihat berbagai aspek, baik aspek yuridis normatif Qur'ani, juga aspek benturan kultur Islami yang sudah mengakar.

Umat bagaikan terbius oleh konsep-konsep baru, sehingga bukannya menyandingkan konsep Islam yang sudah baku dengan konsep yang baru diperoleh dari luar, bahkan telah terhipnotis dan terinjeksi oleh pandangan yang sangat menggoyahkan aqidah dan bisa meruntuhkan iman dengan sebuah statemen bahwa semua agama itu sama atau memandang bahwa konsep Islam telah kadaluarsa. ${ }^{5}$

Berkaitan dengan hal tersebut, maka perlu diuraikan lebih lanjut tentang pendidikan Islam plural dan multikultural yang bagaimanakah yang telah diterapkan dalam pendidikan Islam?

\section{UNIVERSALISME DAN MULTIKULTURAL}

Multikulturalisme sering dipersepsi sebagai politik pengajaran dan nilai keragaman pada tatanan masyarakat plural. Dua istilah tersebut sebenarnya terkait erat dengan dunia pendidikan yang satu dengan yang lainnya tidak saling mengecualikan (mutually exclusive), bahkan dapat dikatakan ibarat dua sisi uang yang berbeda.

Diperlukan landasan pengetahuan yang berupa konsep-konsep yang relevan dan mendukung keberadaan multikulturalisme antara lain demokrasi, keadilan dan hukum, nilai-nilai budaya dan etos, kebersamaan dan perbedaan yang sederajat, suku bangsa, keyakinan keagamaan, ungkapanungkapan budaya, domain privat dan publik, HAM, dan konsep-konsep lain yang relevan. ${ }^{6}$

Isu multikulturalisme sebenarnya tidak terlepas dari tatanan politik global. Sinyalir bahwa Dunia Barat yang kini sedang berupaya mengubah tatanan dunia baru agar menjadi "miliknya" mengangkat isu multikulturalisme sebagai tema penting yang ditawarkan dalam mengubah citra ma- 
syarakat heterogen. Memang diakui bahwa dalam prinsip pendidikan multikultural misalnya, pengakuan terhadap perbedaan menjadi hal yang sangat diutamakan. Hak asasi individu atau kelompok apapun bentuk keunikannya memperoleh tempat yang terhormat di mata multikulturalisme.

Dari sinilah kemudian berkembang semangat komunitas yang mencampuradukkan antara keragaman dengan keagamaan, antara yang eksoterik dengan yang esoterik. Setiap keunikan budaya dibiarkan berkembang, namun pada saat yang sama interaksi trans-budaya yang inferior dengan budaya yang superior dapat menyebabkan semakin lunturnya nilai-nilai budaya pada kalangan minoritas yang cenderung inferior. Karena salah satu elemen pembentuk kebudayaan adalah agama, maka keadaan ini sesungguhnya dapat menggambarkan terjadinya pengikisan nilai-nilai agama secara perlahan.

Risalah agama diturunkan kepada umat manusia untuk mengembangkan cita-cita luhur, sebagai panduan ilahiah bagi perwujudan tatanan makhluk yang damai, penuh rahmat, harmonis, adil dan sejahtera. ${ }^{7}$

Secara ideal tidak ada masalah dalam ketentuan normatif agama, semua berujung pada kebaikan universal, baik dalam relasi vertikal antara manusia dengan Allah (hablun min-Allah), maupun dalam relasi horizontal sesama manusia (hablun min-annas), baik di dunia maupun di akherat kelak. Namun secara faktual, tidak jarang, agama justru menjadi dalih untuk memicu konflik, atau minimal menjadi sumber pembenaran atas berlangsungnya sengketa berdarah. Sampai-sampai sebagian sosiolog berpendapat, bahwa agama disamping berfungsi sebagai pemersatu, juga pemecah belah, seperti misalnya faktor fanatisme agama yang menjadi pemicu terjadinya perang salib (yang banyak merugikan dua belah pihak).

Pada kejadian semacam itu, dampak multikulturalisme dapat menerobos jauh pada wilayah nilai-nilai intrinsik suatu keyakinan agama. Saat nilai agama sudah dilenturkan untuk mengikuti irama masyarakat yang plural, maka batas-batas elemen identitas suatu komunitas beragama dipastikan akan semakin kabur manakala berada dalam posisi yang kalah jumlah, kalah kualitas, dan kalah power. Sementara di lain pihak komunitas beragama yang memiliki superioritas budaya, ekonomi, dan politik akan semakin diuntungkan.

Karena itu, dengan asumsi agama berperan penting dalam pembentukan budaya, maka apa yang terkandung dalam gagasan multikulturalisme sesungguhnya menyangkut eksistensi agama itu sendiri. Agama bukan hanya diakui sebagai kekayaaan yang unik, melainkan bisa menjadi sesuatu yang ikut lebur dalam tempat percampuran (melting pot) budaya 
yang diakui sebagai milik bersama. Kekalahan dalam perang nilai dapat melahirkan penyakit schizophrenia, kepribadian ganda, atau bahkan kehilangan jati diri sama sekali pada kalangan generasi muda. ${ }^{8}$

John Elposito, seorang profesor dari Georgetown University yang memiliki perhatian besar terhadap Islam mensinyalir adanya dampak multikulturalisme dan pluralisme terhadap sistem keyakinan suatu komunitas Muslim. Bagi Elposito, pengakuan terhadap keragaman yang ada dalam agama lain tidak harus melemahkan sistem keyakinan umat Islam. Pencampuran budaya pada masyarakat plural di belahan dunia Barat tampaknya masih diimbangi oleh kemampuan menimbang secara kritis terhadap pengalaman hidup yang penuh tantangan akibat perbedaan. Namun tidak demikian dengan apa yang terjadi dalam masyarakat kita. Multikulturalisme yang dipromosikan melalui dunia maya yang kemudian diakses oleh televisi, VCD, film, dan lain-lain, diakui ataupun tidak, telah membentuk kerelaan sosial kawula muda secara masal untuk menerima budaya orang lain yang sebenarnya dapat membengkokkan keyakinan kita terhadap kaidah agama. Di sisi lain, gerakan intelektual yang cenderung kebablasan dalam menerjemahkan toleransi beragama juga sesekali terjadi. ${ }^{9}$

Multikultural merupakan sifat yang menunjukkan adanya keragaman budaya dalam suatu masyarakat. Untuk mewujudkan nilai-nilai budaya yang multikultural, yang mempunyai keragaman budaya, menurut Parsudi Suparlan acuan utamanya yaitu sebuah idiologi yang mengakui dan mengagungkan perbedaan dalam kesederajatan baik secara individu maupun secara kebudayaan. ${ }^{10}$ Seperti dikemukakan di atas bahwa berbagai konsep yang relevan dengan multikulturalisme antara lain demokrasi, keadilan, dan hukum, nilai-nilai budaya dan etos, kebersamaan dan perbedaan yang sederajat, suku bangsa, keyakinan keagamaan, ungkapanungkapan budaya, domain privat dan publik, HAM, dan konsep-konsep lain yang relevan. ${ }^{11}$

Salah satu cara paling efektif untuk mewujudkan masyarakat multikultural adalah melalui pendidikan. Sebab pendidikan dengan berbagai komponen yang terlibat merupakan lembaga yang mampu memfasilitasi terjadinya desiminasi dan pengembangan multikulturalisme, seperti melalui kurikulum, guru, dan strategi pembelajaran. Dikaitkan dengan berbagai konsep yang relevan dengan multikultural di atas, maka pendidikan harus memberikan bekal tentang civic values ${ }^{12}$ kepada peserta didik, sehingga siap menerima dan menghargai adanya perbedaan yang disebabkan oleh faktor agama, etnis, ras, bahasa, dan gender. Karena itu pendidikan yang multikultural di sini adalah proses pembelajaran yang memungkinkan tumbuh 
dan berkembangnya civic values, sehingga terbentuk generasi yang mengakui dan mengagungkan perbedaan dalam kesederajatan baik secara individual maupun secara kebudayaan.

Pendidikan yang perspektif multikultural ini paling tidak didasari oleh munculnya berbagai konflik dan kekerasan bernuansa etnis dan agama yang terjadi di berbagai daerah yang sedikit banyak merupakan andil dari proses pendidikan selama ini.

\section{KONSEP PENDIDIKAN ISLAM YANG PLURALIS}

Wacana pluralis, menjadi begitu penting dan krusial, karena terkait dengan hal penting dan sensitif, yaitu masalah teologis. Tidak semua umat beragama sepakat mengatakan bahwa ternyata ada kebenaran lain di luar agamanya. Ajaran kitab suci masing-masing agama selalu mengarahkan pemeluknya untuk meyakini bahwa hanya agama tersebut yang paling benar. Meskipun, dalam beberapa hal, dalam kitab suci masing-masing agama ada yang menyatakan secara tersirat adanya 'jalan lain' di luar agamanya, yang bisa jadi juga merupakan jalan yang absah untuk dilalui dalam prosesi menuju Tuhan, tetapi tidak serta merta harus terjadi homogenitas keyakinan pada setiap penganutnya. ${ }^{13}$ Oleh karena itu dalam konsep Islam, kerukunan tetap terjalin tetapi harus memiliki konsistensi yang istiqamah terhadap keyakinannya.

Berkaitan itu oleh Parathazham dari India, menyimpulkan penyebab terjadinya konflik antar umat beragama, yaitu: pertama, kebanyakan kasus antar umat beragama terjadi karena diprovokasi dan disulut oleh politisi demi kepentingan suara dalam pemilihan umum. Kedua, semakin komplek ilmu pengetahuan umat beragama, semakin terbuka dan toleran sikap mereka. Semakin mengenal agama-agama lain semakin toleran dan terbuka sikap umat beragama. ${ }^{14}$

Quraish Shihab, menyatakan "salah satu kelemahan manusia adalah semangatnya yang menggebu-gebu, sehingga ada di antara mereka yang bersikap melebihi Tuhan, misalnya menginginkan agar seluruh manusia satu pendapat, satu aliran dan satu agama, semangat inilah yang hendak memaksakan pandangan absolutnya untuk dianut orang lain"15

Dalam konsep pendidikan Islam, manusia senantiasa dipandang secara integral dan seimbang. Oleh karena itu wajarlah kalau pendidikan Islam dituntut untuk menawarkan pendidikan yang universal dan mampu mengayomi seluruh aspek peserta didik secara utuh, baik sebagai makhluk individu, sebagai makhluk Tuhan maupun aspek sosial.

Menurut Sayyid Quthb, pendidikan Islam adalah sistem pendidikan yang menekankan pada pola pendidikan yang menyeluruh dan mampu 
menyentuh seluruh potensi yang dimiliki peserta didik dan aspek kehidupan manusia. Materi pendidikan (pelajaran harus mampu menstimulir fitrah peserta didik, baik itu fitrah rohani, akal dan perasaan, sehingga memberikan corak serta sekaligus mewarnai segala aktivitas hidupnya di muka bumi, baik sebagai khalifah fil ardh maupun sebagai hamba. Bentuk materi pelajaran yang demikian akan mampu meng-hasilkan sosok peserta didik sebagai manusia seutuhnya (al-Insan al-Kamil). Selanjutnya dalam kaitannya dengan macam pendidikan Muhammad Quthb berdasarkan ciriciri manusia yang baik dan oleh sistem Islam tersebut, diusahakan diterapkan di dunia nyata, yaitu keterpaduan yang lengkap, keserasian, kepositifan, realisme yang idealisme. ${ }^{16}$

Ketika peradaban Islam mencapai kejayaannya, di masa pemerintahan Abbasiah, (Al-Ma'mun dan al-Mutawakkil), pemujaan terhadap akal sangat menonjol, sehingga seakan tradisi umat Islam (yang identik dengan tradisi Islam) yang tidak rasional harus ditinggalkan. Namun kemudian, umat Islam lebih tertarik pada ilmu-ilmu tradisional (agama) dari pada ilmu-ilmu rasional (umum) dengan argumen adanya pandangan yang secara terus menerus diungkapkan bahwa ilmu itu luas sedangkan hidup ini hanya sementara, maka orang Islam harus memprioritaskan sains-sains agama yang merupakan kunci kejayaan hidup di akhirat. ${ }^{17}$

Raimundo Panikkar menulis, bahwa untuk memahami ajaran Islam sacara komprehensif, kita harus memahami agama itu melalui bahasa aslinya. Dan diakuinya bahwa setiap agama merefleksikan, membenarkan, dan melawan yang lain. ${ }^{18}$ Memahami suatu agama secara parsial berarti menggiring kita pada perbedaan yang mengarah pada terciptanya jarak antara satu dengan lainnya. Jarak yang dimaksud, bukan hanya disebabkan karena perbedaan agama tetapi dengan penganut agama yang sama juga dapat terjadi. Untuk mewujudkan pluralisme agama yang harmonis, tidaklah semudah yang diucapkan, tetapi suatu proses yang intens, dengan didukung keterlibatan tokoh-tokoh dari masing-masing agama. Mendalami ajaran suatu agama, tidak berarti harus konversi agama, tetapi dengan studi secara menyeluruh maka akan memahami persamaan dan perbedaan. Pemahaman akan persamaan, mengantar pada keharmonisan dan kerukunan di tengah-tengah masyarakat beragama. Sedang pemahaman akan perbedaan, memberikan toleransi diantara mereka. Zakiyuddin mengutip pendapat Hick, seorang teolog, bahwa pluralisme agama mengimplikasikan pengakuan terhadap pondasi bersama bagi seluruh varitas pencarian agama dan konvergensi agama-agama dunia. Bagi sebagian lainnya, pluralisme agama, mengimplikasikan saling menghargai di antara berbagai pandangan dunia (world-view) dan mengakui sepenuhnya per- 
bedaan tersebut. Jika yang pertama menekankan kebebasan beragama individu, maka yang kedua menekankan pengakuan atas dominasi sebagai pemberi jawaban khas.

Menurut Fuad Jabali, ajaran Islam yang sesungguhnya adalah yang diketahui oleh Allah sendiri. Karena agama Islam untuk umat manusia, maka Allah menurunkan Al-Qur'an yang berasal dari-Nya. Untuk menyampaikan isi ajaran Al-Qur'an, Nabi Muhammad saw. ditunjuk sebagai perantara. Dalam ajaran Islam, tidak memaksakan dengan membatasi penganutnya apalagi penganut agama lain, bahkan memberikan legitimasi atas eksistensi individu, sepanjang tidak mengusik ketenangan pihak lain. Karena itu, perlunya berpikir kritis-analitis dan menjadi alat intelektual untuk pengembangan berbagai keilmuan termasuk agama. ${ }^{19}$ Oleh karena itu setiap komponen dalam proses pendidikan harus dipersiapkan secara terpadu, seperti kurikulum, tenaga pengajar,dan metode pembelajarannya termasuk kajian terhadap media dan lingkungan pendidikan.

Pendidikan Islam di Indonesia masih menghadapi berbagai masalah dalam berbagai aspek. Upaya perbaikannya belum dilakukan secara mendasar, sehingga terkesan seadanya saja. Selama ini, upaya pembaharuan pendidikan Islam secara mendasar, selalu dihambat oleh berbagai masalah mulai dari persoalan dana sampai tenaga ahli. Padahal pendidikan Islam dewasa ini, dari segi apa saja terlihat goyah terutama karena orientasi yang semakin tidak jelas. ${ }^{20}$

Berdasarkan uraian tersebut, maka penulis memandang adanya kesan dikotomi antara pendidikan duniawi dengan ukhrawi sehingga seakan mereka memandang (a) konsep dan praktek pendidikan Islam dirasakan terlalu sempit, artinya terlalu menekankan pada kepentingan akhirat, sedangkan ajaran Islam menekankan pada keseimbangan antara kepentingan dunia dan akhirat. Maka perlu pemikiran kembali konsep pendidikan Islam yang betul-betul didasarkan pada asumsi dasar tentang manusia yang akan diproses menuju masyarakat madani seperti digambarkan pada awal tulisan ini, (b) lembaga-lembaga pendidikan Islam yang dimiliki sekarang ini, belum atau kurang mampu memenuhi kebutuhan umat Islam dalam menghadapi tantangan dunia modern, sehingga dominasi pendidikan yang terkategori maju dan berperadaban modern didominasi oleh pendidikan di Barat yang konotasinya non Islam. Sehingga diperlukan konsep pendidikan Islam yang mampu menjawab seluruh tantangan yang kini telah mengglobal, serta peran sertanya secara mendasar dalam memberdayakan umat Islam baik dari sisi sumber daya manusia maupun dari sisi sarana dan prasarana. Lembaga-lembaga pendidikan harus mampu memenuhi keinginan untuk menjadikan lembaga-lembaga tersebut 
sebagai tempat untuk menimba ilmu umum dan ilmu agama serta keterampilan. Tetapi pada kenyataannya penyesuaian tersebut lebih merupakan peniruan dengan tambal sulam atau dengan kata lain mengadopsi model yang telah dilakukan oleh lembaga-lembaga pendidikan umum, seakan berkata "apa yang dapat dilakukan oleh lembaga-lembaga pendidikan umum dapat juga dilakukan oleh lembaga-lembaga pendidikan agama", sehingga akibatnya beban kurikulum yang terlalu banyak dan cukup berat dan bahkan terjadi tumpang tindih.

Lembaga-lembaga pendidikan Islam mengambil secara utuh semua kurikulum [non-agama] dari kurikulum sekolah umum, kemudian tetap mempertahankan sejumlah program pendidikan agama, sehingga banyak bahan pelajaran yang tidak dapat dicerna oleh peserta didik secara baik, akibatnya produknya [hasilnya] serba setengah-tengah atau tanggung baik pada ilmu-ilmu umum maupun pada ilmu-ilmu agama. Untuk itu, lembaga-lembaga pendidikan Islam sebenarnya mulai memikirkan kembali desain program pendidikan untuk menuju masyarakat madani, dengan memperhatikan relevansinya dengan bentuk atau kondisi serta ciri masyarakat madani. Maka untuk menuju "masyarakat madani", lembaga-lembaga pendidikan Islam harus memilih satu di antara dua fungsi yaitu apakah mendesain model pendidikan umum Islami yang handal dan mampu bersaing secara kompetitif dengan lembaga pendidikan umum atau mengkhususkan pada desain pendidikan keagamaan yang handal dan mampu bersaing secara kompetitif, misalnya mempersiapkan ulama-ulama dan mujtahid-mujtahid yang berkaliber nasional dan dunia.

Konsep dasar pembaharuan pendidikan harus didasarkan pada asumsi-asumsi dasar tentang manusia menurut ajaran Islam, filsafat dan teori pendidikan Islam yang dijabarkan dan dikembangkan berdasarkan asumsi-asumsi tentang manusia dan lingkungannya. Atau dengan kata lain pembaharuan pendidikan Islam adalah filsafat dan teori pendidikan Islam yang sesuai dengan ajaran Islam, dan untuk lingkungan ( sosial - kultural).

\section{PENDIDIKAN ANTARA ISLAM DAN BARAT}

Pluralis dan multikultural adalah identik dengan term globalisasi saat ini, yang bukan hanya satu sisi saja tetapi homogenisasi dan hegemonisasi. Homogenisasi yakni gejala meningkatnya kesamaan di tingkat global, sedangkan hegemonisasi adalah konsentrasi kekuasaan pada suatu negara atau peradaban.

M.A. Muqtedar Khan dan Liem Siok Lan (Justiani) menjelaskan, globalisasi sebagai sebuah gejala mempunyai tiga perkembangan utama 
yaitu: pertama, modal dan integrasi ekonomi men-jadi satu pasar tunggal, kedua transportasi dan komuniksasi, dan ketiga, konvergensi kepentingan di antara kelompok-kelompok dan timbulnya koorporasi multinasional. Ketiga hal tersebut, merupakan manipestasi dari budaya dunia (global culture). ${ }^{21}$

Persoalan pluralisme memang 'layak' diperdebatkan, baik pluralisme dalam tataran konseptual teoretis maupun pluralisme dalam tataran praksis atau kenyataan hidup umat beragama. Sebelum fatwa MUI keluar soal ini, wacana pluralisme sebetulnya sudah tumbuh seiring dengan merebaknya pemikiran liberalisme di Indonesia tahun 70-an. Nurcholish Madjid waktu itu yang menjadi ikon intelektualnya.

Dari sisi teologispun sebetulnya masih banyak kontroversi dan silang pendapat. Dalam Islam, misalnya, ada beberapa ayat Al-Qur'an yang secara tekstual menyatakan bahwa pluralisme merupakan sesuatu yang sah, seperti, Allah berfirman:

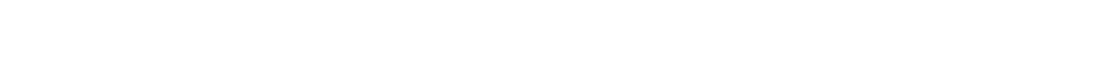

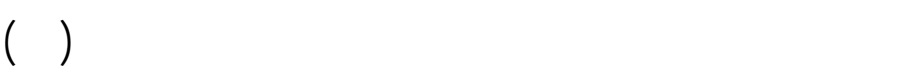

Sesungguhnya orang-orang mukmin, orang-orang Yahudi, orang-orang Nasrani dan orang-orang Shabiin, ${ }^{22}$ siapa saja diantara mereka yang benarbenar beriman kepada Allah, hari kemudian dan beramal saleh, mereka akan menerima pahala dari Tuhan mereka, tidak ada kekhawatiran kepada mereka, dan tidak (pula) mereka bersedih hati. ${ }^{23}$

Di sisi lain, ayat Al-Quran pun menyatakan secara tegas bahwa pluralisme tertolak dengan sendirinya. Kebenaran hanya ada pada agama Islam. Sementara itu, tidak ada kebenaran di luar Islam, sebagaimana Allah swt. telah berfirman :

\section{国

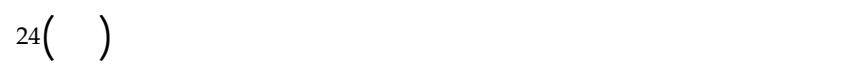

Sesungguhnya agama (yang diridhai) di sisi Allah hanyalah Islam. tiada berselisih orang-orang yang Telah diberi Al Kitab kecuali sesudah datang pengetahuan kepada mereka, Karena kedengkian (yang ada) di antara mereka. barangsiapa yang kafir terhadap ayat-ayat Allah Maka Sesungguhnya Allah sangat cepat hisab-Nya.

Bahkan lebih tegas Allah swt. memberikan penekanan sebagai berikut:

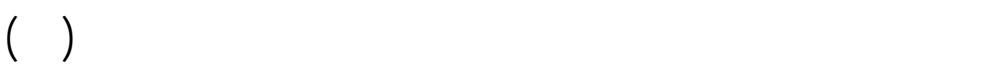


Barangsiapa mencari agama selain agama Islam, maka sekali-kali tidaklah akan diterima (agama itu)daripadanya, dan dia di akhirat termasuk orangorang yang rugi. 25

Kedua model ayat di atas menurut masing-masing pihak yang pro maupun kontra soal pluralisme, menjadi justifikasi teologis. Dengan kata lain, ada landasan konkret dalam kitab suci firman Tuhan sendiri.

Itulah sebabnya oleh fatwa Majelis Ulama Indonesia (MUI) pernah menyatakan haram paham pluralisme, sekulerisme, dan liberalisme itu, sehingga sampai kini masih terus menghangat sebagai diskursus publik, antara pro dan kontra terhadap paham-paham itu. Silang pendapat para pemikir keagamaan dalam tataran teoritis konseptual di satu sisi, dan dalam tataran praksis, publik juga merespons dengan nada yang berbeda, di sisi yang lain.

Konsekuensinya, kedudukan paham pluralisme adalah sama absahnya dengan kedudukan pahan anti-pluralisme. Dengan demikian, paham pluralisme sendiri sebetulnya tidak perlu dipersoalkan, apalagi dilarang. Pluralisme, salah satunya, adalah juga hasil dari pembacaan terhadap teksteks suci, bahkan Nabi saw. sebagaimana dijelaskan sebelumnya telah mempraktekkan hidup dalam keragaman, namun karena mereka berkhianat terhadap nabi, maka Rasulullah mengusirnya yang waktu itu pemegang hegemoni politik adalah Nabi.

Selain itu, pemahaman akan Tuhan itu sendiri juga masih berpotensi memunculkan diskursus yang panjang. Ibnu Arabi, misalnya, ketika mencoba memahami Tuhan, ia menemukan tiga hal penting. Pertama, Tuhan yang mutlak dalam 'kesendirian.' Tuhan dalam tingkatan ini tidak ada seorangpun yang dapat menjangkaunya. Hanya Dia sendiri yang tahu akan diri-Nya sendiri.

Kedua, Tuhan yang sudah tersifati. Misalnya ada sifat al-rahman, alrahim, dan sebagainya. Teologi Asy'ariyah dalam tradisi pemikiran Islam, misalnya, mengatakan adanya 20 sifat yang 'wajib' bagi Tuhan dan 20 sifat yang 'mustahil' bagi-Nya. Ada pula yang menetapkan adanya 99 nama atau sifat (al-asma al-husna) bagi Tuhan. Dalam Kristen, paham trinitas dalam banyak hal juga terkait dengan sifat Tuhan yang mereka yakini. Dalam Hindu, banyaknya para 'dewa' juga merupakan representasi dari adanya sifat-sifat Tuhan seperti yang mereka yakini. ${ }^{26}$

Ketiga, Tuhan yang telah 'bersemayam' dalam akal pikiran manusia. Dalam tataran ini, masing-masing manusia akan berbicara tentang Tuhan sesuai dengan apa yang ia baca dalam akalnya. Ini berpotensi besar melahirkan aneka ragam bentuk dan pola penafsiran. Tuhan yang dipahami oleh kalangan filosof bisa jadi sangat berbeda dengan Tuhan yang dipa- 
hami oleh kalangan sufi ataupun ahli fikih. Itu semua merupakan hasil yang lahir dari sebab pergulatan pemikirannya ketika membaca teks-teks suci. Wacana pluralisme adalah salah satunya. ${ }^{27}$

Pada hakikatnya, tidak ada satu manusiapun yang mampu memahami Tuhan dalam 'realitas-Nya' yang konkret dan hakiki secara utuh. Manusia hanya dapat mendekati Tuhan, akan tetapi tidak akan mampu menjangkau-Nya secara utuh. Al-Ghazali mengistilahkannya dengan satu ungkapan yang sangat menarik, "Semakin aku mencoba mendekat untuk memahami Tuhan, semakin aku sadar kalau aku tidak mampu memahamiNya." Konsekuensi logisnya, setiap manusia sejatinya sedang menuju Tuhan. Tidak ada yang dapat memastikan jalan kebenaran yang pasti dan mutlak untuk menuju-Nya.

Masalah kebenaran agama adalah masalah keyakinan. Kalau sudah masuk dalam tataran ini, maka sebetulnya tidak ada seorangpun yang dapat memaksakan satu bentuk keyakinan tertentu terhadap keyakinan orang lain. Walaupun para penganut agamanya mencoba merasionalisasikan agamanya, namun pada akhirnya akan pada satu kesimpulan bahwa agama adalah masalah keyakinan. Adanya agama-agama yang berbeda di penjuru muka bumi ini merupakan kata lain bahwa keyakinan manusia sejatinya memang berbeda-beda.

Orang Yahudi misalnya mengklaim bahwa mereka adalah umat (manusia) pilihan, sebagai perantara Tuhan untuk menyampaikan wahyu kepada umat manusia. Untuk menjadi Yahudi harus mempunyai hubungan khusus dengan Tuhan. Sementara Agama Budha mengklaim bahwa, Dharma adalah yang memelihara kebenaran penuh, penjelasan yang khusus dan efektif serta akhir diantara illuminasi dan wahyu tentang dunia. Adapun kalangan kristen, Yesus kristus adalah peletak dasar dan pusat agama, dia juga Tuhan dalam bentuk manusia, mereka meyakini bahwa agama mereka adalah satu-satunya agama yang benar. Dalam kristen Katolik, diyakininya bahwa tidak ada keselamatan diluar gereja, sehingga bagi yang tidak bergabung dengan gereja sebelum mati, akan binasa dalam api kekal yang disediakan bagi syaitan dan cucunya.

Dalam Islam, ada kepercayaan tegas bahwa Nabi Muhammad adalah Nabi dan melalui Al-Qur'an Tuhan telah mewahyukan akan kebenaran agama Islam. Agama yang paling benar disisi Tuhan adalah Islam, segala penyembahan harus kepada Allah, selain-Nya adalah syirik. Syirik balasannya adalah kekal dalam neraka. ${ }^{28}$

Sepanjang pengamatan Tracy,29 walaupun ada kemiripan, dintara agama-agama tersebut tidak ada yang memiliki esensi tunggal, tidak ada muatan tunggal tentang pencerahan atau wahyu, tidak ada cara tunggal 
tentang emansipasi atau liberasi yang dibangun dalam semua pluralitas itu. Ada perbedaan penafsiran tentang Tuhan itu sendiri. Ada perbedaan pemahaman mengenai apa yang diwahyukan oleh Tuhan termasuk cara yang diikuti mengubah cara pandang menuju pemusatan kepada Tuhan secara bebas. Masing-masing punya cara yang berbeda-beda, dan selain itu, mereka berbeda dalam hal Tuhan yang mereka sembah.

Pada suatu peradaban terdapat dua macam tradisi, yaitu kategori great tradition dan little tradition. ${ }^{30}$ yang pertama merupakan tradisi bagi mereka yang suka berpikir, kelompok ini relatif sedikit. Sedang yang kedua sebagai tradisi dari sebagian besar orang yang menerima apa adanya tidak pernah memikirkan secara mendalam tradisi yang mereka miliki, menerima dari pendahulunya apa adanya dan tidak pernah diteliti dan disaring pengembangannya.

Hemat penulis, wacana pluralisme yang kembali menghangat saat sekarang ini sudah selayaknya disikapi dengan arif dan bijaksana oleh siapapun. Anggapan tentang adanya kebenaran dari berbagai sumbernya yang juga kebenaran menurut para penganut agama-agama yang lain, tidak saja layak dihormati, namun juga mesti diapresiasi dalam bentuk kerja sama yang konkret dan bernilai positif bagi umat manusia secara menyeluruh.

Sisi positif paham pluralisme jangan sampai terlupakan. Paham pluralisme, hingga saat sekarang ini, cenderung dilihat dari sisi teoritis konseptual semata. Maka, wacana yang berkembang kurang melihat realitas yang berimbas dari paham pluralisme itu sendiri. Pluralisme, dari segi positifnya, jelas menawarkan adanya toleransi yang tinggi pada setiap umat beragama. Masing-masing mereka akan menghormati umat dari luar agamanya.

Pluralisme agama juga memberikan nilai-nilai positif bagi kehidupan berbangsa dan bernegara. Khusus di Indonesia pluralisme jelas mengakomodir pasal 29 ayat 2 Undang-Undang Dasar (UUD) 1945. Dalam negara demokrasi yang menjunjung tinggi hak asasi manusia, hak dan kebebasan beragama, diberikan tempat yang sangat luas. Maka, dalam konteks ini, paham pluralisme agama hendaknya tidak disikapi dengan model berpikir yang arogan dan otoriter.

Sikap arif dan bijaksana adalah kata akhir untuk paham apapun, termasuk paham pluralisme itu sendiri. Ada dua sikap pada kalangan umat beragama pada umumnya, yaitu: Pertama lebih bersifat universal dan terbuka dan yang kedua bersifat partikuler, sempit dan sangat tertutup. Yang pertama kebanyakan dianut oleh kalangan cendekiawan, dan kelas menengah. Nilai-nilai yang menjadi pegangan dan acuan adalah ke- 
taatan pada aturan serta rasionalitas. Sangat interpretatif-kontekstual, puritan, literal, hidup sederhana, egaliter dan eksatik. Sedangkan yang kedua dianut oleh kalangan pedesaan dan masyarakat yang lebih sederhana. Hidupnya diliputi oleh unsur magis, pemujaan kepada orang-orang suci seperti wali, mereka menggunakan ayat-ayat suci sebagai penyembuhan. Itu adalah sebagian kecil corak keIslaman umat Islam, berdasarkan tingkat pemahaman terhadap dali-dalil baik dari Al-Qur'an maupun hadis Nabi Muhammad saw.

Harus di akui, bahwa agama-agama, disamping memiliki klaim absolutisme, juga memiliki klaim inklusivisme. Dalam konteks ini ada kasus menarik yang pernah dialamai oleh Nabi Muhammad saw., yaitu ketika kaum musyrik bersih keras menolak ajaran Islam, maka demi kemaslahatan bersama, Tuhan memerintahkan kepada Nabi untuk berkata kepada mereka, sebagaimana tercantum dalam Q.S. 34. ayat 24-26:

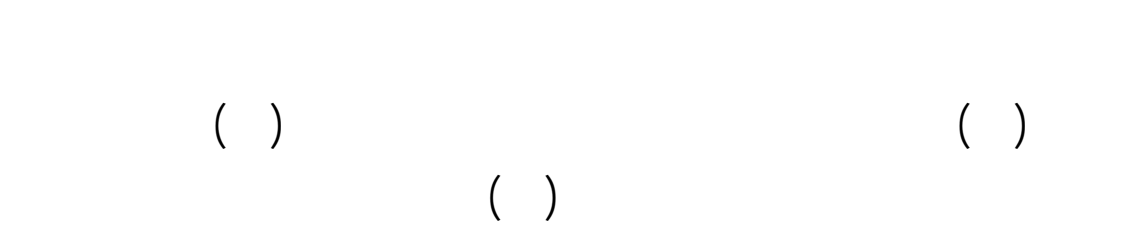

Katakanlah: "Siapakah yang memberi rezeki kepadamu dari langit dan dari bumi?" Katakanlah: "Allah", dan Sesungguhnya kami atau kamu (orangorang musyrik), pasti berada dalam kebenaran atau dalam kesesatan yang nyata."Katakanlah: "Kamu tidak akan ditanya (bertanggung jawab) tentang dosa yang kami perbuat dan kami tidak akan ditanya (pula) tentang apa yang kamu perbuat". "Katakanlah: "Tuhan kita akan mengumpulkan kita semua, Kemudian dia memberikan keputusan antara kita dengan benar. dan Dia-lah Maha pemberi Keputusan lagi Maha Mengetahui".

Ayat Al-Qur'an tersebut, mengingatkan kepada kita bahwa sejak kelahiran Islam tidak pernah Nabi Muhammad saw. memaksakan bagi kaum kafir Quraisy untuk memeluk kecuali dengan cara mengajak mereka berpikir dan membuka hati dan akal sehatnya.

Secara umum John Hedrik Meuleman, seperti dikutip oleh M. Zainuddin dalam jurnal el-Harakah, melihat adanya beberapa kelemahan tradisi ilmiah di kalangan Muslim yaitu, pertama, adanya logosentrisme, tekstualis yang mengabaikan unsur tak tertulis dari agama dan kebudayaan Islam, seperti tindakan sosial, seni dan seterusnya; kedua sikap apologetik terhadap aliran (teologi, Fikih dst); dan yang ketiga adanya kecenderungan yang verbalistik dan memberikan wibawa terlalu besar terhadap tradisi, yang berimplikasi pada sikap eksklusivisme. ${ }^{31}$ 
Perkembangan studi Islam di Indonesia nampaknya menjanjikan masa depan yang menggembirakan, sebab jika dilihat dari watak dasarnya, Islam adalah agama yang terbuka. Oleh sebab perkembangan semacam ini secara akademik akan menjanjikan. Karena itu rekontruksi Islam di Indonesia sebagai objek kajian akan lebih banyak didominasi oleh ilmuan Islam, yang kebanyakan mereka melakukakan dekonstruksi orientalism, yang menekankan watak konservatif, statis dengan disiplin filologi yang ketat-menjadi lebih empiiris, reflektif dan humanis. ${ }^{32}$

\section{PENUTUP}

Islam adalah agama terbuka, tidak menutup diri, dan memberikan kebebasan berpikir bagi penganutnya, dan ajarannya mengajak penganutnya untuk senantiasa berinteraksi antar sesama manusia tanpa membedakan antara satu dengan yang lain serta menghimbau untuk senantiasa berdialog mencari kebenaran yang hakiki dengan pihak lain (non Islam) dan dilakukan secara baik-baik.

Pendidikan Islam yang plural, adalah pendidikan yang mengarahkan peserta didik untuk mampu menjalin kerja sama dengan pihak lain tanpa membedakan latar belakang, etnis, warna kulit, agama dan kepercayaan. Kesiapan untuk mengakui akan eksistensi pihak lain, maka berarti telah berada pada kemampuan menerapkan paham pluralis, namun dengan keragaman yang ada dalam lingkungan, tidak harus melemahkan sistem keyakinan umat Islam.

Pencampuran budaya pada masyarakat plural di belahan dunia Barat tampaknya masih diimbangi oleh kemampuan menimbang secara kritis terhadap pengalaman hidup yang penuh tantangan akibat perbedaan.

Pendidikan formal di sekolah, yang juga mencakup proses pembelajaran agama Islam, tentu juga dapat memberikan pencerahan dengan pendekataan pluralistik melalui pengembangan kurikulum, misalnya pengajaran aqidah, ilmu fikih dan akhlak, dapat disisipkan pahampaham/sekte-sekte, demikian pula mazhab-mazhab yang oleh penganut mazahib saling menghargai antara satu dengan lainnya, sehingga keterbiasaan sejak dini memahami perbedaan itu akan tertanam toleransi di tengah-tengah masyarakat.

\section{CATATAN AKHIR}

1. Di dalam al-Quran diperintahkan untuk memahami Islam secara kaffah (Q.S. 2: 208).

2. Tidak ada paksaan untuk (memasuki) agama (Islam); sesungguhnya telah jelas jalan yang benar daripada jalan yang sesat. Karena itu barangsiapa yang ingkar 
kepada Thaghut dan beriman kepada Allah, maka sesungguhnya ia telah berpegang kepada buhul tali yang amat kuat yang tidak akan putus. Dan Allah Maha Mendengar lagi Maha Mengetahui. Lihat Q.S. 2 (al-Baqarah ayat 256)

3. Lihat Ahmad Syalabi, Sejarah dan Kebudayaan Islam, Jilid I, Jakarta: PT. AlHusana Zikra, 2000, hal. 133. Lihat pula Abu Muhammad Abdul Malik bin Hisyam al-Muwafiri, As-Sirah an- Nabawiyah li Ibni Hisyam, Jilid II, Beirut: Darul fikr, 1415 H/1994 M., hal. 41 dan 176.

4. Lihat Philip K. Hitti, Histori of Arabs, New York: Palgrave Macmillan, 2002, hal.147.

5. Bandingkan dengan Wawancara Prof. Dr. Salman Harun, MA., dengan judul "Maqsith salah Tafsir" dalam majalah Tabligh edisi 8 April 2008, vol. 06. hal 16.

6. Parsudi Suparlan, Menuju Masyarakat Indonesia Yang Multikultural (Makalah) Simposium Internasional, Denpasar: Jurnal Antropologi Indonesia, Juli 2002, h. 3.

7. Lihat al-Quran Surat al-Anbiya ayat 107.

8. Dikutip oleh Rahmat Mulyana, Multikulturalisme dan Nilai Agama; Harian Pikiran Rakyat, Bandung edisi 1 Nopember 2006.

9. Rahmat Mulyana, loc. cit.

10. Parsudi Suparlan, op. cit, h. 3.

11. Ibid.

12. Yang dimaksud dengan civic values di sini adalah nilai-nilai kewargaan yang harus dimiliki dalam setiap peserta didik dalam konsep multikultural seperti demokrasi, hak asasi manusia, toleransi, pluralisme dan kesetaraan gender.

13. Lihat Mufid, Reformasi Hukum Menuju Masyarakat Madani, Makalah "Seminar Nasional dan Temu Alumni, Program Pascasarjana Universitas Muhammadiyah Malang", Tanggal, 25-26 September 1998.

14. Sebagaimana dikutip oleh J.B. Banawiratma dalam Andito, (ed.), Atas Nama Agama Wacana Agama dalam Dialog "Bebas" Konflik, Bandung: Pustaka Hidayah, 1998, h.99.

15. Quraish Shihab, Membumikan al-Quran, Bandung: Mizan, 1992, h. 222.

16. Sayyid Quthb, Fi Zhilal al-Quran, Beirut: Dar al-Syuruq, 1975, h. 19.

17. Lihat Sutrisno, Pemikiran Pendidikan Kritis dan kreatif menurut Fazlur Rahman (Jurnal), Ilmu Pendidikan Islam, Yogyakarta: Fak.Tarbiyah dan Keguruan UIN Sunan Kalijaga, Vol. 5, 2004, h. 152-53.

18. John Lyden, Enduring Issues In Religion, San Diego: Greenhaven Press, 1995, h. 86.

19. Fazlur Rahman, Islam and Modemity: Transformation of an Intellectual Tardition, Chicago and London: The University Of Chicago Press, 1982, h. 157.

20. Muslim Usa, Pendidikan Islam di Indonesia antara Cita dan Fakta, Yogyakarta: Tiara Wacana, Cet. I, 1991, h. 11-13.

21. Liem Siok Lan (Justiani), Mengapa Islam Indonesia Menjadi Penentu Dunia Bangkit atau Hancur?, (Makalah) disajikan pada Seminar Internasional, UIN Alauddin Makassar, 15 November 2008, h. 1.

22. Lihat Penjelasan dalam Departemen Agama RI. Al-Quran dan Terjemahnya AlBaqarah ayat 62. Bandingkan terjemahan pada Tafsir Jalalain.

23. Departemen Agama RI., Al-Quran dan Terjemahnya, Bandung: Jumanatul Art, 2004, h. 10.

24. Lihat Tafsir Jalalain (Q.S. Ali Imran/3: 19). 
25. Departemen Agama RI, Al-Quran dan Terjemahnya, S. Ali Imran/3: ayat 85.

26. Fajar Kurnianto, Sebuah Kearifan untuk Faham Pluralisme, Jakarta: Jaringan Islam Liberal, 2007, edisi 2 September 2007.

27. Ibid.

28. John Hick, Problem of Religious Pluralism, London: The Macmillan Press, 1985, h. 48.

29. David Tracy, Plurality and Ambigity, Hermaneutic, Religion, Hope, Chicago: Universitas Press, 1987, h. 90.

30. M. Bambang Pranowo, Islam Faktual Antara Tradisi dan Relasi Kuasa, Yogyakarta: Adicita Karya Nuasa, 1983, h. 3.

31. M. Abdurrahman, Menuju Pemahaman Agama Yang Plural, Jurnal el-Harakah edisi 62, Malang: el-Harakah, 2005, h. 41.

32. Ibid, hal 42.

\section{DAFTAR PUSTAKA}

Al-Qur'an al-Karim.

Abdurrahman, M., Menuju Pemahaman Agama Yang Plural, Jurnal el-Harakah edisi 62, Malang: el-Harakah, 2005.

Andito, Atas Nama Agama Wacana Agama dalam Dialog "Bebas" Konflik, Bandung: Pustaka Hidayah, 1998.

Departemen Agama RI., Al-Quran dan Terjemahnya, Bandung: Jumanatul Art, 2004.

Harun, Salman, "Maqsith salah Tafsir", majalah Tabligh edisi 8 April 2008, vol. 06.

Hick, John, Problem of Religious Pluralism, London: The Macmillan Press, 1985.

Hitti, Philip K., Histori of Arabs, New York: Palgrave Macmillan, 2002.

Kurnianto, Fajar, Sebuah Kearifan untuk Faham Pluralisme, Jakarta: Jaringan Islam Liberal, 2007, edisi 2 September 2007.

Lan, Liem Siok, Mengapa Islam Indonesia Menjadi Penentu Dunia Bangkit atau Hancur?, (Makalah) disajikan pada Seminar Internasional, UIN Alauddin Makassar, 15 November 2008.

Lyden, John, Enduring Issues In Religion, San Diego: Greenhaven Press, 1995.

Mufid, Reformasi Hukum Menuju Masyarakat Madani, Makalah "Seminar Nasional dan Temu Alumni, Program Pascasarjana Universitas Muhammadiyah Malang", Tanggal, 25-26 September 1998.

Mulyana, Rahmat, Multikulturalisme dan Nilai Agama; Harian Pikiran Rakyat, Bandung edisi 1 Nopember 2006.

Muwafiri, Abu Muhammad Abdul Malik bin Hisyam, As-Sirah an- Nabawiyah li Ibni Hisyam, Jilid II, Beirut: Darul fikr, 1415 H/1994 M.

Pranowo, M. Bambang, Islam Faktual Antara Tradisi dan Relasi Kuasa, Yogyakarta: Adicita Karya Nuasa, 1983.

Quthb, Sayyid, Fi Zhilal al-Quran, Beirut: Dar al-Syuruq, 1975.

Rahman, Fazlur, Islam and Modemity: Transformation of an Intellectual Tardition, Chicago and London: The University Of Chicago Press, 1982.

Shihab, Quraish, Membumikan al-Quran, Bandung: Mizan, 1992.

Suparlan, Parsudi, Menuju Masyarakat Indonesia Yang Multikultural (Makalah) Simposium Internasional, Denpasar: Jurnal Antropologi Indonesia, Juli 2002. 
Sutrisno, Pemikiran Pendidikan Kritis dan kreatif menurut Fazlur Rahman (Jurnal), Ilmu Pendidikan Islam, Yogyakarta: Fak.Tarbiyah dan Keguruan UIN Sunan Kalijaga, Vol. 5, 2004.

Syalabi, Ahmad, Sejarah dan Kebudayaan Islam, Jilid I, Jakarta: PT. Al-Husana Zikra, 2000.

Tracy, David, Plurality and Ambigity, Hermaneutic, Religion, Hope, Chicago: Universitas Press, 1987.

Usa, Muslim, Pendidikan Islam di Indonesia antara Cita dan Fakta, Yogyakarta: Tiara Wacana, 1991. 